\title{
The Saga of Peter Still
}

\author{
Spencer R. Crew ${ }^{1}$
}

The following is an expanded and footnoted version of the twenty-fourth annual Louis Faugères

Bishop III lecture, held Monday, February 23, 2009 at the Alexander Library of Rutgers

University in New Brunswick.

Peter Still's story begins in Maryland on the Eastern Shore. This is the same area of the state where years later both Harriet Tubman and Frederick Douglass would be born and would grow to adulthood. Peter Still did not live in Maryland nearly as long as Tubman and Douglass. His life in slavery took a turn much different than the lives of either of these more well known individuals. His story, however, is no less significant. ${ }^{2}$

In the years after the American Revolution the abolitionist movement gained strength in Maryland. Lead by Quakers the abolitionists sought to free enslaved individuals frequently by petitioning the courts to grant them their freedom. The petitioners' arguments were grounded in Maryland laws which based the status of African Americans on the condition of their mothers. The petitioners sought to identify enslaved persons who were descended from a free female ancestor and consequently should be free by law. The most important case in these efforts was that of Mary Butler in 1787. She gained her freedom when she proved she was the great-great granddaughter of a servant, "Irish Nell" Butler who came to Maryland as a free person in 1681 and subsequently married an enslaved man. ${ }^{3}$

The creation of the Maryland Abolitionists Society for Promoting the Abolition of Slavery and the Relief of Poor Negroes and Others Unlawfully Held in Bondage which was organized in Baltimore in 1789, served to increase the influence and the impact of abolitionists in Maryland. Their suits against slavery created a thorny dilemma for slaveholders in the state. No one could predict who might next find himself in court embroiled in a freedom case. Moreover, the court cases could be long and challenging affairs. To defend himself, the slaveholders had to hire legal representation and during the trial the enslaved person in question was removed from the custody of the slaveholder and his or her labor were lost. Thus, even a finding in favor of a slaveholder cost him money and the extended loss of the labor of the enslaved individual. ${ }^{4}$ And it did not ensure he would retain the service of the enslaved person as they might still run off after losing the decision.

Faced with this prospect, it was not unusual for slaveholders to enter into agreements with particularly valuable and headstrong enslaved individuals--those most likely to seek legal

\footnotetext{
${ }^{1}$ Spencer R. Crew is the Clarence J. Robinson Professor of History, George Mason University

${ }^{2}$ William Still, The Underground Railroad Authentic Narratives and First-Hand Accounts (Mineola: Dover Publications, 2007), p. 22.

${ }^{3}$ T. Stephen Whitman, The Price of Freedom Slavery and Manumission in Baltimore and Early National Maryland (Lexington: The University Press of Kentucky, 1997), pp. 63-64;Carter G. Woodson, "The Beginnings of the Miscegenation of the Whites and Blacks," The Journal of Negro History Vol. 3, No. 4 (October, 1918) p. 340.

${ }^{4}$ Jeffery R. Brackett, The Negro in Maryland A Study of the Institution of Slavery (Baltimore: John Murphy and Company, 1889), pp. 52-57; Whitman, pp. 65-66.
} 
redress. The agreements often allowed the enslaved to work to earn their freedom or to have it granted after a specified number of years. This protected the slaveholder from the possibility of a disruptive law suit and gave the enslaved person hope for the future. ${ }^{5}$

It is in this environment that the Still family lived on the Saunders Griffin plantation on the Eastern Shore of Maryland. The enslaved family consisted of six members, the parents Levin and Cidney and their four children, two boys, Levin and Peter as well as two girls Kitty and Kitturah. The issue for them was that the father, Levin, was extremely disgruntled with his enslaved status. He wanted his freedom and emphatically shared his frustrations with Griffin. Reportedly he indicated he would prefer to kill himself or be killed rather than continue to accept enslavement. ${ }^{6}$

Faced with this declaration Griffin had several options. He could sell Levin, separating him from his family and getting rid of a troublesome presence. He could punish Levin and seek to break his will, or he could find a way to accommodate his desires. Griffin decided to fashion an accord with him. The final agreement was that Levin would have the opportunity to do extra work after his normal workday for which he would get paid. He could then use the money accumulated to eventually purchase his freedom.

Levin accepted the arrangement with the hope that Griffin would keep his word. After several years of working late evenings and on weekends, Levin was able to accumulate enough money to purchase his freedom. True to his word, Griffin had manumission papers drawn up and granted Levin his freedom. While pleased to have his freedom Levin's had mixed emotions as his family remained enslaved. Levin realized he could not possibly earn enough money in Maryland to free them as rapidly as he wished. Consequently, Levin relocated to the African American town of Springtown, New Jersey near the Delaware River hoping he could find more lucrative work there. $^{7}$

This was the public explanation he offered for his departure, though he and Cidney had an alternative plan in mind. Levin told her he would find a place outside of Philadelphia along the Delaware River where he would wait for her. She was to wait a few weeks to allay any suspicion and then join him bringing the four children. Their ruse worked exactly as they had planned it. She and the children left late one evening in 1805. The two boys who were less than ten years old had the responsibility of helping her with the two younger girls. Their escape entailed several hard days of travel. They covered more than 100 miles in the process before they finally reunited with Levin. Happy to be together again in the free state of New Jersey the family looked to the future. Levin found employment at a local sawmill and the family sustained itself on his salary and food they grew or foraged in the nearby countryside.

Unfortunately, events did not follow the plan they had envisioned. Saunders Griffin sought the return of his runaways and sent slave catchers in pursuit of Cidney and the children. Once the

\footnotetext{
${ }^{5}$ Whitman, pp. 66-67.

${ }^{6}$ Charles L. Blockson, The Underground Railroad (New York: Berkley Books, 1994), p. 6; Dennis Brindell

Fradin, My Family Shall Be Free (New York: Harper Collins, 2001), p. 4; (Still 2007), p. 22

${ }^{7}$ George Fishman, The African American Struggle for Freedom and Equality The Development of A People's

Identity, New Jersey, 1624-1850 (New York: Garland Publishing, Inc., 1997), p. 156.
} 
men located the family they waited until Levin was away at work and then seized his wife and children. They placed the family in a wagon and drove them back to Maryland and the Griffin plantation. Angered by Cidney's escape, Griffin punished her by separating her from her children. They were put under the care of another older woman on the plantation. Each evening after completing her work for the day, Cidney was not allowed to see the children, but was confined in the attic of the Griffin home. This was done to insure that Cidney would not run again and to dissuade her from thoughts of escape in the future. This routine was followed for several months. Griffin hoped the prolonged separation from her children would sap her desires for freedom. ${ }^{8}$

When Griffin finally allowed Cidney to return to her children he believed she had learned her lesson and would not run again. But, the outcome of the punishment was not what Griffin had hoped. Instead of giving up on the idea of freedom, Cidney was even more determined to shed the bonds of enslavement. She was so determined that she made a very difficult decision as she prepared her plans to escape a second time. ${ }^{9}$

The first trip to join Levin was very difficult. Traveling at night through the countryside with four children was a nearly impossible task. Keeping them quiet, traveling over unfamiliar terrain, and avoiding detection made it a very arduous experience. This time Cidney determined she could not take all four children with her. Only two of them could come and she had to decide which children would remain enslaved and which would go with her to freedom. It had to be an agonizing choice for Cidney. The kind of choice no parent ever wishes to have to make. She decided to take the two younger girls and to leave the boys. She probably felt they had a better chance of successfully navigating the tribulations of enslavement than did the girls. One of her concerns may have been the terrible jeopardy especially faced by females in slavery. Women and girls often found themselves at the complete mercy of their slaveholder with little or no recourse available to them. Cidney also hoped she might come back for the boys at a later time.

Once she resolved to leave with the girls, Cidney decided to depart without letting the boys know she was going. She slipped away in the middle of the night leaving them in the care of her mother. One of the reasons Cidney may not have informed the boys of her plan was to protect them from Griffin. If they did not know her plans, they could not reveal anything to Griffin which might shield them from punishment.

The second trip to join Levin was just as difficult as the first trip even though she only had two children. The trip was so tiring that Cidney had to leave the youngest girl hidden by the side of the road as they neared the end of their journey because she could not carry her any further. Levin retraced her steps and retrieved the child before any harm came to her. ${ }^{10}$

This time Cidney's efforts resulted in long term success for the family. They relocated to an isolated area on the New Jersey side of the Delaware River in a place called Indian Mills. This

\footnotetext{
8 (Blockson 1994), p. 6; (Still 2007), p. 22.

9 (Blockson 1994), p. 7; William J. Switala, Underground Railroad in New York and New Jersey (Mechanicsburg: Stackpole Books, 2006), p. 50.

${ }^{10}$ (Blockson 1994), p. 7; (Still 2007), p. 23
} 
was about 25 miles east of Philadelphia in the Pine Barrens region of the state. Cidney changed her name to Charity and the family adopted the last name of Still. This change of name and location worked as Griffin was not able to find the family and they settled successfully into their new life. ${ }^{11}$

For the two boys, Levin Junior and Peter, their mother's departure resulted in an immediate change in their status. Within hours after Cidney's departure Griffin sold both of the boys to a slave trader on his way further south. The slave dealer put them into a wagon and traveled 500 miles to the city of Lexington, Kentucky. There they both were sold to a local landowner, John Fisher, for about $\$ 150.00$ each. The boys actually were fortunate in that they were both sold to the same individual and allowed to work together, first at his home in the city of Lexington and then on his plantation outside of the city. Staying together provide some solace to the two young men during their initial days in their new circumstances. ${ }^{12}$

Eventually, Fisher decided to put both the boys to work in his brickyard in Lexington. It was hard and dirty work. Their task was to take the finished bricks, place them in a wheel barrel, push them into the warehouse where they stacked the bricks, and then repeat the process. For boys of approximately eleven and nine this was a very difficult work assignment. The oven for baking the bricks made the place very hot and whenever they slowed down the foreman was there with his whip to provide incentive to keep up the pace. They spent the next several years working in the brickyard.

After four years, Fisher decided to sell the brickyard and the enslaved people who worked in it. Once again the two boys were sold to the same person in Lexington, Nathaniel Gist, who also owned a brick factory. However, their work routine changed. During the summer months they worked in the brick factory, but in the winter months they were hired out as workers for other city residents so that Gist could profit from their labor. In 1817 after four years more the boys' circumstances changed again. For the first time they were separated, as Levin was sent to Alabama with the nephew of Gist to begin a new business.

Their separation lasted about a year until Gist died and his remaining slaves were sent to Alabama to join his nephew. Levin and Peter spent more than thirty years in Alabama. During that time they both married. Levin married first and was brutally punished for choosing a mate of whom his slaveholder, Levi Gist, did not approve. For his audacity, Levin was severely beaten and suffered from the after affects of the whipping for many years. Peter also married, but is more fortunate in that his union with Fanny, a woman from a neighboring plantation, received the approval of Gist. They had their first of four children within about a year and fashioned a comfortable life for their family within the constrictions of their enslavement. ${ }^{13}$

But, tragedy struck in 1831 when Levin's condition began to deteriorate rapidly. He finally died from his earlier injuries. Levin represented Peter's only tie to the family he lost years before and his death was a severe blow to Peter. They had shared the dream of one day gaining their

\footnotetext{
11 (Still 2007), p. 23.

${ }^{12}$ Kate E. R. Pickard, The Kidnapped \& The Ransomed The Narrative of Peter and Vina Still after Forty Years of Slavery (Lincoln: University of Nebraska Press, 1995), pp. 26-29.

${ }^{13}$ (Pickard 1995), pp. 112-113.
} 
freedom and returning to the Philadelphia area and reuniting with their parents. With Levin's death Peter worried the dream might never occur. While Peter had his own family to care for, he did not lose the hope of one day gaining his freedom. ${ }^{14}$

Unfortunately, Levin's death was just the first of several major changes in Peter's life over the next decade. Nathaniel Gist also died and his widow remarried placing control of her property and her enslaved people in the hands of her new husband. Up until that point Peter's responsibilities had been primarily around the house and in the stables. With the arrival of a new head of the household, a man named John Hogun, Peter was sent to work as a field laborer planting, caring for, and harvesting cotton. He performed this backbreaking work for the next six years.

Peter's circumstances changed when it was decided to hire him out to provide additional income for the household. In this role he worked in a variety of jobs, including field hand, school janitor, handyman for a minister, shop clerk for a local merchant, and cook. The money he earned in these jobs was given to his slaveholder with only a small portion given him to provide for his own needs.

His circumstances improved when he was hired out to a bookstore owner who struck a private side deal with Peter. He allowed Peter to hire his own time away from the bookstore. The agreement was that Peter would pay him a fixed amount and that Peter might keep any funds he earned above that amount for himself. This was a terrific arrangement for Peter who had not given up his dreams of freedom and was determined to save enough to buy himself just as his father had done. ${ }^{15}$

This was a wonderful dream, but a huge challenge for Peter. Conditions were not such as to make this an easy goal to accomplish. First, it was not very likely that Mr. Hogun, his present slaveholder would allow Peter to buy himself. Alabama law made it very difficult for a slaveholder to give or sell freedom to an enslaved person. Hogun would have to go to court and get permission from a judge in order to free Peter. Then there was the added challenge that by law another slaveholder could sue Peter's slaveholder to prevent the manumission, a practice employed to discourage those who considered emancipation.

The challenge for Peter was to devise a plan which allowed him to purchase his freedom in the face of these obstacles. Besides the issues previously mentioned there was also the problem which confronted any enslaved person who entered into an agreement with someone white. Because helping a slave buy their freedom was illegal any agreement had to be verbal. There were no written contracts. This meant the enslaved person had to depend upon the integrity of the other person to do as he promised. This was a precarious assumption to depend upon. Peter had heard of stories of enslaved individuals who claimed their slaveholder had agreed to sell them their freedom but when the required amount was accumulated they denied the agreement and confiscated the money. In addition, Peter had to insure that Hogun did not know in advance that he had been preparing buy his freedom. If Hogun learned the subterfuge which Peter had in

${ }_{15}^{14}$ (Pickard 1995), pp. 135 - 137; (Still 2007), p. 23.

15 (Pickard 1995), pp. 209-212.

16 Alabama Slave Law Summary and Record, http://www.slaveryinamerica.org/geography/slave_laws_AL.htm 
mind, the repercussions would be swift. At minimum Peter could expect a physical beating for his troubles or even worse he might be sold further south and permanently separated from his wife and children. Peter did not want this to happen to him. ${ }^{17}$

Good fortune befell Peter when he procured a position working in a general store in the town of Tuscumbia, Alabama. It was owned by two Jewish brothers, Joseph and Isaac Friedman. They were the first and only Jews in the town and were tolerated by the local residents despite their religious beliefs. Peter initially did odd jobs for them while still functioning under his agreement with the bookstore operator. During that time he paid close attention to their conversations, especially when they expressed their beliefs concerning slavery and emancipation. From their comments he believed they might help him with his plan.

His first task was to ascertain whether they would be willing to hire him out from Hogun when his time with the bookstore owner ended. He broached the possibility with them and the brothers agreed to hire his time. The brothers subsequently reached agreements with Hogun and then with Peter. The verbal contract with Peter was that he would work a set number of hours each week for them in the store and then could use the remaining time to find other work and keep the money he made. This worked well for Peter as it allowed him to continue to set aside money for his freedom fund.

The three of them renewed the agreement after the first year and it was then that Peter decided to approach the Friedman's about his grander plan. He had to approach the topic carefully because if he had misjudged their sentiments he was opening himself up to great danger. When he finally broached the topic the brothers were supportive of the idea. Despite the legal jeopardy they faced in deciding to help, the brothers agreed to buy him from Hogun. Peter would then repay them that amount and obtain his freedom. ${ }^{18}$

When the Friedman's first suggested the idea of purchasing Peter from Hogun they were rebuffed. Even though Peter was an older slave at nearly 50 years of age, Hogun was loath to lose the regular income Peter generated. Peter could continue to work for them, but Hogun would not sell him unless the Friedman's would pay him what they thought was an unreasonably high price. The brothers continued to discuss the matter with Hogun and after a year he agreed to allow them to buy Peter for $\$ 500$.

It took Peter little more than a year to earn the remaining money needed to purchase his freedom. When he presented it to the Freidman brothers they kept their word and gave Peter his freedom papers. However, because of Alabama law they did not make their agreement public. At minimum he would have to leave the state immediately and at worse the Freidman's could be prosecuted and Peter thrown back into enslavement. Instead, Peter continued to work for them as their "slave" as he decided what to do after informing his wife of the good news. His plan was to earn enough money to go north and try and find his mother, father, and sisters. Once reunited with them he hoped to earn additional money to buy the freedom of his wife and children.

\footnotetext{
${ }^{17}$ (Pickard 1995), pp. 213-214

18 (Pickard 1995), pp. 219 - 220; (Still 2007), p. 1.
} 
As it turned out one of the brothers, Isaac decided to travel to Cincinnati, Ohio to visit with his family. Peter was to go with him and then return later to continue working at the store. After saying goodbye to his family Peter left with Isaac in July of 1850. They took a riverboat up the Tennessee River to the Ohio River to Cincinnati. Peter stayed in Cincinnati for a short period and then headed up river to Pittsburgh then on to Philadelphia. In Philadelphia he hoped to gain information about his parents and reconnect with his family. ${ }^{19}$

When he arrived in Philadelphia Peter hoped to make contact with someone who might help him in his quest. This was not a simple process as Peter had to be very careful about whom he contacted. While he was now free, slave catchers kidnapped both fugitives and free people to carry them south for sale. Peter did not want this to happen to him at this stage of his quest. Eventually he was told he should meet with a young man who worked for the Pennsylvania AntiSlavery Society. Most people fleeing slavery who passed through the city had contact with this individual or one of his colleagues. They said this man also knew most of the African American families who lived in the region. Peter hoped he might have news of his family.

Their meeting was providential. Peter was cautious when first introduced to the young man, but decided to share his story of nearly forty years with him. He told the man about his life on the Eastern Shore of Maryland, of his father's purchase of his own freedom, of his mother and sister's escape to New Jersey, and the years he and his brother spent in slavery. As he told his story Peter was troubled by the reaction of the young man. At first he diligently wrote down the details of Peter's story. But as Peter continued the young man ceased writing and began staring intently at Peter. This gave Peter great concern as he was not sure what was on the mind of the young man. His greatest fear was that the young man was about to turn him over to slave catchers or that he found Peter's story unbelievable.

Neither of these ideas was what was bothering the young man, William Still. Instead he was surprised and gratified by the story he was hearing. In a letter he wrote later William described his feelings as Peter's story unfolded.

Last Friday afternoon, Peter Friedman was brought to this office by a man whom I was partially acquainted with; the object of Peter was to see if he could gain some instruction [in] how he might find his parents and relatives whom he had been sold away from for 43 years. The remarks made by the stranger much surprised me and I soon began to make inquirery as to his parents and their names. He immediately gave the names of his father, Mother, and the brother who was also sold with him at the same time. By this time I perceived that a wonderful development was about to be made. My feelings became unutterable (?) although I endeavored to surprise them with much effort, but the fact that this Peter was one of my long absent brothers stared me too full in the face to gainsay or dispute the evidence for one moment. Thus a brother whom I had never before seen was introduced to me in this most wonderful manner. It would afford me much pleasure to make further statement concerning this matter but for (__ ?_ ) of time I must fanfare (?) at present. Suffice it to say that Peter found his Mother, 5 brothers, and 3 sisters situated comfortably in life.

From Peter's youngest brother, Wm Still

${ }^{19}$ (Pickard 1995), pp. 233-236; (Still 2007), pp. 1-2. 


\section{No 31 North fifth St. Philadelphia $\mathrm{Pa}^{20}$}

When William revealed his relationship to Peter, he was stunned to have reconnected to his family so rapidly. What followed was an emotional reunion between Peter and his mother and his two sisters after 40 years of separation. Peter learned that his parents had finally settled in New Jersey not far from Philadelphia. To make it harder for them to be found again they had changed names. His mother became Charity and they adopted the last name of Still. The couple had fourteen additional children over the years. Unfortunately, Levin senior had died some years earlier. William was the youngest and had been living in Philadelphia for a number of years along with two of his sisters. When Peter met him, William was the chairman of the Pennsylvania Society for the Abolition of Slavery. His job was to aid fugitives who came through Philadelphia by providing food, clothing, shelter, work, and transportation further north. This was the reason Peter was sent to William in the first place. $^{21}$

Peter's story might have ended happily with the reunion with his long lost family. But, Peter had another family he had left in Alabama and who waited to join him in freedom. When he left Tusculum he had promised his wife, Vina that he would find a way to return and gain her freedom and that of their children. Peter did not forget that promise in the joy of his reunion with his mother and siblings. Instead, he sought to enlist the help of William and others to find a way to free his own family. This would turn into a four year effort to reunite with his family.

Against William's advice, Peter decided to return to Alabama and investigate ways of freeing his family. He planned initially to travel to Cincinnati and to re-contact Isaac Friedman when he arrived there. Peter and Isaac devised a plan which had Peter returning to Alabama under the guise that he was still the slave of the Friedman's and they had sent Peter back ahead of their own return. When he arrived in Tuscumbia Peter learned that Hogun was willing to sell his family to Friedman for $\$ 3000$. Buoyed by this news and the hope of seeing his family again, Peter returned to Cincinnati to discuss the matter with Friedman. Unfortunately, Isaac had moved to Indiana and Peter decided to return to Philadelphia in the hope of acquiring the needed funds there.

In Philadelphia, he talked with William and requested his help in securing the manumission fee. Their efforts are not successful as the Still family did not have access to that much money and could not find enough additional contributors. But as Peter and William traveled about telling Peter's story, they were introduced to Seth Concklin, a former soldier, abolitionist, and participant in the Underground Railroad. Concklin was captivated by Peter's story and offered to travel to Alabama to free Vina and the children. William and others were unsure about Concklin as well as the ultimate success of such an effort, and they sought to discourage Peter from doing business with him. However, Concklin convinced Peter of his commitment and received Peter's permission. ${ }^{22}$

\footnotetext{
${ }^{20}$ Peter Still Papers, 1850-1875, Alexander Library, Rutgers University

${ }^{21}$ James O. Horton, "A Crusade for Freedom William Still and the Real underground Railroad" in David W. Blight, editor Passages to Freedom The Underground Railroad in History and Memory (Washington, D. C.: Smithsonian Press, 2004) pp. 189-190.

22 (Pickard 1995), pp. 376-398.
} 
Concklin left for Alabama in January of 1851. What followed was both heroic and tragic. After traveling for several weeks Concklin arrived in Tuscumbia and made contact with Vina. She knew Concklin was sent by Peter because he brought a gingham cape which she had given Peter with the understanding that whoever returned it could be trusted. They then agreed upon a plan of escape for Vina and her three children. Posing as Concklin's slaves they would travel up river to Indiana and from there continue north to safety and freedom. ${ }^{23}$

They left as planned in March of 1851 taking a small boat and rowing it up the Tennesse River to the Ohio River. After more than seven days of traveling they landed in New Harmony, Indiana. Although Indiana was a free state they were not safe as slave catchers and slavery sympathizers abounded along its southern border. Despite their precautions and efforts the party was captured a week after arriving in the state. Vina and the children were held in jail in Vincennes, Indiana while word was sent out to find their slaveholder. Concklin, who was not with them when they were captured, visited them regularly with the hope that he might free them. Instead he also was arrested and taken with Vina and her family to return to Alabama. Tragically, Concklin did not reach Tuscumbia. He was separated from the group and found mysteriously drowned with his hands and feet chained and his skull fractured. The men who held him captive claimed he just disappeared one evening and must have fallen overboard. Vina and the family were returned to Tuscumbia where they were punished for escaping and Vina was forced to live by herself isolated from her children and everyone else on the plantation. ${ }^{24}$

When Peter learned of the failure of the rescue attempt he was heartbroken but not broken in spirit. He remained determined to free his family and immediately sought an alternative means of attaining their emancipation. Through contacts he made in Cincinnati, Peter was able to inquire whether Vina's slaveholder would reconsider and sell her and the children to Peter. After several weeks of waiting for a response William received a letter from B. McKiernan who claimed ownership of Peter's family. He expressed great frustration with Concklin, Peter and Vina for the escape attempt, but offered to sell the four family members for $\$ 5000{ }^{25}$

While the news that McKiernan had agreed to sell Peter his family was encouraging, the sum he demanded was overwhelming. It was more than the $\$ 3000$ he previously had suggested to the Friedman brothers. And, it remained a sum far beyond the ability of the Still family to raise alone. Peter then developed an alternative plan. It was not uncommon for individuals seeking funds to free a loved one to travel to a variety of northern cities giving presentations about their plight and soliciting funds to purchase enslaved family or friends. Peter felt this approach offered his best opportunity to raise the monies needed. He informed McKiernan he would raise the money for his family and put his plan in motion.

In order to get strangers in different cities to allow him to speak to a group of their friends or associates Peter needed to get trusted individuals to vouch for his character and the validity of his challenge. He began by deciding to approach a woman from New York who had taught in a school in Tuscumbia where Peter had worked. They had spoken frequently while she lived in

${ }^{23}$ (Still 2007), pp. 4-5.

${ }^{24}$ Wilbur. H. Siebert, The Underground Railroad From Slavery to Freedom A Comprehensive History (Mineola: Dover Publications, 2006), pp. 160-162, (Still 2007) ,pp. 1-17.

${ }^{25}$ (Still 2007), pp. 17-18 
Alabama and he hoped she would attest to the validity of his story and plight. Eventually he was able to contact her and she agreed to write a letter verifying Peter's story and his good character. Her name was Kate E. R. Pickard who was from a prominent family in Syracuse. She wrote a letter of support for Peter detailing his history and the veracity of his plight. Her letter, along with the letters of several prominent New Jersey residents who had come to know Peter, allowed him to begin his speaking tour. ${ }^{26}$

Peter's travels took him to numerous northern states where he spoke to a variety of individuals and groups. Harriet Beecher Stowe was among them, and she wrote a letter noting “...I am satisfied that his is a case that calls for compassion and aid. " He also received letters of support from Horace Greely, Gerrit Smith, and other prominent abolitionists. It took him nearly two years of traveling and speaking, but by August of 1854 he had raised $\$ 5000$. $^{27}$

When told Peter had raised the money, McKiernan attempted to increase the price to $\$ 6000$ but was held to his original price. A white friend of the Still family from Philadelphia was sent to Alabama with the money to "purchase" Peter's family. Vina, her daughter, and two sons were allowed to leave per the agreement. However, one son had a young child who McKiernan refused to send with the family. He claimed the two year old boy was not part of the original agreement. He offered to sell him to Vina for an additional two hundred dollars which he knew no one in her family could afford. In the end Vina was forced to leave her grandson behind. ${ }^{28}$

Peter reunited with his family in a bittersweet meeting. He was overjoyed to see his wife and children, but brokenhearted to learn that a grandson he had never seen was left behind. Eventually the family returned to Burlington County in New Jersey where Charity and Peter's other siblings lived. Though they tried, the family was never able to retrieve their grandson. They did receive information that the young man was doing well in Alabama, though he remained enslaved. He did not reunite with his family until after the Civil War. ${ }^{29}$

Peter and Vina finally settled in Burlington County to be near his mother and other family members. They both obtained work at a boardinghouse and eventually purchased a small farm not far from Charity. One of the most important steps they took was to make their marriage binding in the eyes of the law when they married officially on June 25, 1855 about twenty-nine years after their "marriage" on the McKiernan plantation. It was a reaffirmation of their commitment to each other and a rebuke of the control McKiernan and others had tried to have over their lives. $^{30}$

Peter remained in Burlington for the next twelve years until his death in 1867 of pneumonia. He and Vina become respected members of the African American community and were founding members of the Second Baptist Church, the oldest African American church in Burlington County. They also allowed the teacher who wrote the initial letter of support for Peter, Kate E. R. Pickard, to write their story which she published in 1856. William Still continued his

\footnotetext{
${ }^{26}$ Peter Still Papers, 1850-1875, Alexander Library, Rutgers University

27 Ibid.

${ }^{28}$ (Fradin 2001), pp. 148-157;(Pickard 1995), pp. 319-338, 369.

29 (Fradin 2001), p. 172.

30 (Pickard 1995), pp.375-376.
} 
Crew

activities with the Pennsylvania Anti-Slavery Society which provided the material for his book The Underground Railroad Authentic Narratives and First-hand Accounts which included Peter's story. It is primarily through the writings of Pickard and William Still that Peter and Vina's story was preserved. 